\title{
Identifying and Defining the Dimensions of Community Capacity to Provide a Basis for Measurement
}

\author{
Robert M. Goodman, $\mathrm{PhD}$ \\ Marjorie A. Speers, $\mathrm{PhD}$ \\ Kenneth McLeroy, $\mathrm{PhD}$ \\ Stephen Fawcett, PhD \\ Michelle Kegler, DrPH \\ Edith Parker, PhD \\ Steven Rathgeb Smith, PhD \\ Terrie D. Sterling, PhD \\ Nina Wallerstein, DrPH
}

\begin{abstract}
Although community capacity is a central concern of community development experts, the concept requires clarification. Because of the potential importance of community capacity to health promotion, the Division of Chronic Disease Control and Community Intervention, Centers for Disease Control and Prevention (CDC), convened a symposium in December 1995 with the hope that a consensus might emerge regarding the dimensions that are integral to community capacity. This article describes the dimensions that the symposium participants suggested as central to the construct, including participation and leadership, skills, resources, social and interorganizational networks, sense of community, understanding of community history, community power, community values, and critical reflection. The dimensions are not exhaustive but may serve as a point of departure to extend and refine the construct and to operationalize ways to assess capacity in communities.
\end{abstract}

Robert M. Goodman is an associate professor in the Department of Community Health Sciences, Tulane University School of Public Health and Tropical Medicine, New Orleans, LA. Marjorie A. Speers is a deputy associate director for science at the Centers for Disease Control and Prevention (CDC), Atlanta, GA. Kenneth McLeroy works in the Department of Health Promotion Sciences, College of Public Health, University of Oklahoma Health Sciences Center. Stephen Fawcett is a member of the Work Group on Health Promotion and Community Development, University of Kansas. Michelle Kegler is an assistant professor in the Department of Health Promotion Sciences, College of Public Health, University of Oklahoma Health Sciences Center. Edith Parker works in the Department of Health Behavior and Health Education, University of Michigan School of Public Health, Ann Arbor. Steven Rathgeb Smith works at the Graduate School of Public Affairs, University of Washington, Seattle. Terrie D. Sterling works in the Division of Adult and Community Health, National Center for Chronic Disease Prevention and Health Promotion, CDC, Atlanta, GA. Nina Wallerstein is the director of the Department of Family, Community, and Emergency Medicine, School of Medicine, University of New Mexico. 
Building community capacity is a central concern of community ${ }^{1-4}$ and organizational development experts, ${ }^{5,6}$ funding agencies, ${ }^{7}$ and implementing organizations. ${ }^{8}$ All share the view that community capacity is a necessary condition for the development, implementation, and maintenance of effective, community-based health promotion and disease prevention programs. Because of the importance of community capacity to health promotion, the Division of Chronic Disease Control and Community Intervention, Centers for Disease Control and Prevention (CDC), convened a 2-day symposium in December 1995. The CDC invited community health researchers from the United States and Canada to join CDC community specialists with the hope that a consensus might emerge regarding the dimensions that are integral to community capacity. The participants represented a wide range of disciplines, including community health development, health education, community psychology, epidemiology, anthropology, political science, and sociology. (The participants included the authors and those mentioned in the acknowledgments.) The CDC envisioned the symposium as a first step in operationalizing capacity so that it might be better defined, measured, and used to help communities diagnose their assets and select appropriate interventions for further capacity development.

Weeks prior to the meeting, the participants shared relevant articles. At the meeting, participants engaged in a series of facilitated exercises, including (1) an open discussion of capacity based on the readings, (2) a brainstorming session in which elements of capacity were listed, (3) a synthesis session in which similar items from the brainstorming session were combined into dimensions of capacity, and (4) a small group exercise in which participants were assigned to work groups that corresponded to each dimension. The work groups began to identify a literature that explains each dimension and reported back to the entire symposium at the closing session. Over the next several months, the work groups further researched the dimensions and submitted their written findings for this article. The literature was drawn from the many disciplines that reflect the diverse orientations of symposium members.

Symposium participants began with two working definitions of community capacity: (1) the characteristics of communities that affect their ability to identify, mobilize, and address social and public health problems ${ }^{9}$ and (2) the cultivation and use of transferable knowledge, skills, systems, and resources that affect community- and individual-level changes consistent with public health-related goals and objectives. ${ }^{10}$ Participants felt that community capacity should stand in contrast to other popular approaches to community health and development, such as health risk factor and needs assessments. ${ }^{11}$ Rather than focus exclusively on risks, needs, or other deficits, assessments also should emphasize community capacity as assets to address the presenting health concerns. ${ }^{3,12-14}$ A refined understanding of community capacity would aid in such assessments. Armed with this understanding, health promotion specialists could assess community assets before initiating community projects. If they find capacity is lacking, interventions can focus first on building capacity, thus enhancing both community assets and the probability of

Address reprint requests to Robert $\mathrm{M}$. Goodman, $\mathrm{PhD}$, Tulane University School of Public Health and Tropical Medicine, 1501 Canal Street, New Orleans, LA 70112-2824; phone: (504) 584-3539; fax: (504) 584-3540.

Other contributors were Nicholas Freudenberg, DrPH, Hunter College; Catherine Hutsell, CDC; Barbara Israel, DrPH, University of Michigan; John Korn, CDC; Ronald Labonte, PhD; R. Brick Lancaster, CDC; David McQueen, ScD, CDC; Letitia Presley-Cantrell, CDC; Todd Rogers, PhD, Stanford University; and Nancy Watkins, CDC. 
successful project implementation. Without devoting time to the process of capacity building, outcomes may be attenuated. ${ }^{15,16}$

There is no question that the concept of community capacity requires clarification. Often, capacity is used interchangeably with other, similar concepts such as community empowerment, ${ }^{16-19}$ competence, ${ }^{3,20,21}$ and readiness. ${ }^{22,23}$ All of these concepts have contributed to our current understanding of community capacity. But using them interchangeably minimizes important differences that each concept contributes to the development of community health initiatives. For instance, although empowerment shares characteristics with capacity, capacity seems to be a broader construct. Minkler and Wallerstein note that empowered communities gain mastery and "assume greater power or expand their power" (p. 250). ${ }^{24}$ In this article, we view community power as one of several dimensions of community capacity. Also, capacity may be distinguished from competence. We view capacity as a potential state and competence as an active state. That is, capacity reflects a community's potential for addressing presenting health issues, whereas competence signifies how skillfully capacity is applied. Capacity is most similar to readiness in that both are potential states that may lead to community action.

The dimensions of community capacity identified by the working groups at the CDC symposium include participation and leadership, skills, resources, social and interorganizational networks, sense of community, understanding of community history, community power, community values, and critical reflection. Table 1 provides a summary of the dimensions' characteristics, as defined by the work groups and as discussed throughout this article. Table 2 further illustrates some of the ways that the dimensions may be linked: Each column in Table 2 is headed by a capacity dimension; the cells within a column indicate the links between the column heading and the other dimensions. It should be noted that neither Table 1 nor Table 2 provides an exhaustive listing. For instance, many more links are probable than are reflected in Table 2. Also, the nature of the Table 2 matrix restricts links as occurring between only two dimensions when more than two may be linked simultaneously. We view both tables as starting points for increasing precision in defining the dimensions and the relationships among them. It should be further noted that recent discussions of empowerment ${ }^{17,19,25}$ suggest an overall context that applies equally to understanding community capacity: It is a process as well as an outcome; it includes supportive organizational structures and processes; it is multidimensional and ecological in operating at the individual, group, organizational, community, and policy levels (our understanding of community is that it encompasses all these sectors); and it is context specific. Also, communities can lose as well as gain capacity. Capacity exists in a dynamic state and develops in stages of readiness that must be taken into account in selecting capacity-enhancing interventions ${ }^{26,27}$ How capacity is enhanced is an important question that may benefit from the cultivation of enabling systems ${ }^{28}$ We view this article as a first step in identifying the dimensions of capacity without specifying methods for enabling community assets.

\section{DIMENSIONS OF COMMUNITY CAPACITY}

\section{Participation and Leadership}

Participation and leadership are two important and related dimensions of community capacity. These two factors are connected in that a community lacks capacity when its 
Table 1. Dimensions and Subdimensions of Community Capacity

Citizen participation that is characterized by strong participant base

diverse network that enables different interests to take collective action benefits overriding costs associated with participation

citizen involvement in defining and resolving needs

Leadership that is characterized by

inclusion of formal and informal leaders

providing direction and structure for participants

encouraging participation from a diverse network of community participants

implementing procedures for ensuring participation from all during group meetings and events facilitating the sharing of information and resources by participants and organizations

shaping and cultivating the development of new leaders

a responsive and accessible style

the ability to focus on both task and process details

receptivity to prudent innovation and risk taking

connectedness to other leaders

Skills that are characterized by

the ability to engage constructively in group process, conflict resolution, collection and analysis of assessment data, problem solving and program planning, intervention design and implementation, evaluation, resource mobilization, and policy and media advocacy the ability to resist opposing or undesirable influences

the ability to attain an optimal level of resource exchange (how much is being given and received)

Resources that are characterized by

access and sharing of resources that are both internal and external to a community

social capital, or the ability to generate trust, confidence, and cooperation

the existence of communication channels within and outside of a community

Social and interorganizational networks that are characterized by

reciprocal links throughout the overall network

frequent supportive interactions

overlap with other networks within a community

the ability to form new associations

cooperative decision-making processes

Sense of community that is characterized by

high level of concern for community issues

respect, generosity, and service to others

sense of connection with the place and people

fulfillment of needs through membership

Understanding of community history that is characterized by

awareness of important social, political, and economic changes that have occurred both

recently or more distally

awareness of the types of organizations, community groups, and community sectors that are present

awareness of community standing relative to other communities 
Table 1. Continued

Community power that is characterized by the ability to create or resist change regarding community turf, interests, or experiences power with others, not control over them (non-zero-sum or win-win strategies) influence across a variety of domains or community contexts

Community values that are characterized by clearly defined norms, standards, and attributes consensus building about values

Critical reflection that is characterized by the ability to reflect on the assumptions underlying our and others' ideas and actions the ability to reason logically and scrutinize arguments for ambiguity

the ability to understand how forces in the environment influence both individual and social behavior

the ability for community organizations to self-analyze their efforts at change over time

leadership does not have a strong base of actively involved residents. ${ }^{13,29}$ Conversely, participation without the direction and structure that leadership provides often results in disorganization. ${ }^{30}$

Participation is basic to capacity because involvement of individual community members in local events must occur if capacity is to develop. Leaders enhance capacity when they ensure the active involvement of a diverse network of community members, thus enabling disparate interests to take collective action by forming what Steuart has called a "unit of solution." ${ }^{14}$ Moreover, social networks can reinforce participation by connecting individuals to resources and power bases (see linkages noted in Table 2).

A useful way to delineate the characteristics of participation and leadership that enhance community capacity is to consider the following two questions: (1) Who participates and leads? (2) How do they participate and lead?

Who participates and leads? This question can be examined by considering whether participants are representative of the groups residing in a community. Research indicates that participation may not be dependent on demographic characteristics such as race, gender, and age ${ }^{31}$ but rather may be associated with participants' sense of community; ${ }^{32}$ the benefits and costs associated with participation, including structural barriers such as lack of day care or transportation; ${ }^{33}$ expectancies of individual and collective control; ${ }^{34}$ and community members' degree of concern about the issue at hand (see Table 2 ). ${ }^{35}$

Related to the question of who does (and does not) participate is the issue of exclusivity (or, conversely, inclusivity) of community participation. Are community leaders or the community-at-large actively excluding certain types of participants? Although this article argues for following democratic principles in soliciting participation, Brown ${ }^{36}$ emphasizes that in practical application, a community coalition may be less functional when it includes groups that do not support the coalition's mission. For instance, an antismoking coalition may not find it productive to include tobacco proponents as participants.

In considering who leads, capacity may be enhanced by the presence of a diverse or pluralistic leadership in the community. One aspect of pluralism is the interplay between positional leaders, or those who are elected or appointed to leadership positions, and reputational leaders, or those who are serving the community in informal leadership 
positions such as community activists and other opinion leaders who serve as norm setters and community helpers. ${ }^{37,38} \mathrm{~A}$ mix of both of these types of leaders may suggest community capacity. In addition to mixed leadership, considering whether leadership is being transferred, shaped, and cultivated over time should be taken into account. For example, if staff from public health agencies take a lead role in organizing a community initiative, the degree to which they represent the views of community members should be examined, along with whether the leadership is transferred over time to community members, thus cultivating the next generation of leadership.

How do people participate and lead? This question is directed at the values and principles by which community groups operate. Marti-Costa and Serrano-Garcia ${ }^{39}$ point out that without grassroots participation in defining and resolving needs, community empowerment is not possible, and needs assessment can become a process of social control. The literature includes frameworks for grassroots participation such as Arnstein' $\mathrm{s}^{40}$ ladder of citizen participation from nonparticipation (manipulation and therapy) to tokenism (informing and consultation) to degree of citizen power (partnership, delegated power, and citizen control). In addition, Uphoff, Cohen, and Goldsmith ${ }^{41}$ offer a framework for describing and analyzing rural development, and Checkoway and Van $\mathrm{Ti}^{42}$ outline different types of individual and organizational participation.

How people participate is also related to the accessibility of social networks, formal health and social agencies, and mediating structures such as churches and grassroots community groups, which represent individuals in their interactions with formal agencies (see Table 2). ${ }^{43}$ Participation of community members in any organization is dependent on the opportunity that the organization provides for inclusion. Thus, at an organizational level, one may look for both the presence of these organizations and the presence of opportunities for participation that they provide. Wickizer et al. ${ }^{44}$ examine organizational participation in community-based interventions and suggest a measure of interorganizational network development through network-analytic techniques. Similarly, Alter and Hage $^{45}$ provide a model for understanding the stages and conditions under which interorganizational collaboration occurs.

As noted in Table 2, how people participate is further influenced by the skills of community members and their level of volunteerism. Does the group have recognized procedures for ensuring broad participation at meetings and events? Do community participants share information and resources? Do community members participate as volunteers within their own community? Have their efforts resulted in successes that lead other communities to seek their help in solving problems? This latter question illustrates that past experience (community history — see Table 2) may be a prelude for current perceptions of efficacy in problem solving.

As for leaders, research suggests that how they lead influences community participation. Leadership style, ${ }^{38,46}$ decision-making style, ${ }^{47,48}$ networking and visibility, ${ }^{49}$ and political efficacy ${ }^{50}$ may be related to the ability of community groups and coalitions to maintain the participant base needed for their survival. For example, Giarmartino and Wandersman ${ }^{51}$ found that leader control-the "degree to which the leader is given the tasks of directing the group, making decisions, and enforcing rules" (p. 353) - relates to the satisfaction of members of the community group. Kumpfer et al. ${ }^{23}$ found that when leaders encouraged and supported members' ideas and planning efforts, used democratic decision-making processes, and encouraged networking and information sharing among members, work plans were of higher quality, member satisfaction was greater, and members perceived the team as more successful. 
Table 2. Linkages Across the Dimensions of Community Capacity

\begin{tabular}{|c|c|c|c|c|c|}
\hline & Leadership & $\begin{array}{c}\text { Citizen } \\
\text { Participation }\end{array}$ & Skills & Resources & $\begin{array}{c}\text { Social and } \\
\text { Interorganizational } \\
\text { Networks }\end{array}$ \\
\hline Leadership & & $\begin{array}{l}\text { Provides a base } \\
\text { for organizing }\end{array}$ & $\begin{array}{l}\text { Facilitate the leader's } \\
\text { ability to provide } \\
\text { momentum }\end{array}$ & & \\
\hline $\begin{array}{l}\text { Citizen } \\
\text { participa- } \\
\text { tion }\end{array}$ & $\begin{array}{l}\text { Influences direction } \\
\text { and structure of } \\
\text { participation } \\
\text { Facilitates the } \\
\text { maintenance of a } \\
\text { participant base } \\
\text { Removes barriers to } \\
\text { participation } \\
\text { Provides } \\
\text { opportunities } \\
\text { to participate }\end{array}$ & & $\begin{array}{l}\text { Influence quality of } \\
\text { participation in } \\
\text { meetings, } \\
\text { planning, and } \\
\text { activities } \\
\text { Influence member } \\
\text { satisfaction with } \\
\text { planning and } \\
\text { action }\end{array}$ & $\begin{array}{l}\text { Help to attract } \\
\text { participants } \\
\text { Stimulate } \\
\text { mechanisms } \\
\text { for citizen input }\end{array}$ & $\begin{array}{l}\text { Increase the benefits } \\
\text { citizens receive from } \\
\text { participation } \\
\text { Facilitate } \\
\text { frequency/intensity } \\
\text { of participation }\end{array}$ \\
\hline Skills & $\begin{array}{l}\text { Facilitates the } \\
\text { cultivation and } \\
\text { transition of } \\
\text { new leadership } \\
\text { Facilitates planning } \\
\text { and activities }\end{array}$ & $\begin{array}{l}\text { Provides diverse } \\
\text { base of skills }\end{array}$ & & & $\begin{array}{l}\text { Connect complementary } \\
\text { skills }\end{array}$ \\
\hline Resources & $\begin{array}{l}\text { Facilitates the } \\
\text { acquisition of } \\
\text { needed resources }\end{array}$ & $\begin{array}{l}\text { Provides diverse } \\
\text { base of } \\
\text { resources }\end{array}$ & $\begin{array}{l}\text { Influence the } \\
\text { diversity of } \\
\text { resources available } \\
\text { for exchange } \\
\text { Facilitate the } \\
\text { competent use of } \\
\text { resources }\end{array}$ & & $\begin{array}{l}\text { Connect complementary } \\
\text { resources }\end{array}$ \\
\hline $\begin{array}{l}\text { Social and } \\
\text { inter- } \\
\text { organiza- } \\
\text { tional } \\
\text { networks }\end{array}$ & $\begin{array}{l}\text { Fosters diverse } \\
\text { involvement } \\
\text { Can exclude } \\
\text { community } \\
\text { sectors } \\
\text { Promotes network } \\
\text { cohesion }\end{array}$ & $\begin{array}{l}\text { Provides } \\
\text { opportunity to } \\
\text { link different } \\
\text { community } \\
\text { sectors }\end{array}$ & $\begin{array}{l}\text { Influence conflict } \\
\text { resolution among } \\
\text { network members }\end{array}$ & $\begin{array}{l}\text { Influence the number } \\
\text { of mediating } \\
\text { structures } \\
\text { that are active } \\
\text { Can reinforce trust } \\
\text { or increase } \\
\text { competition } \\
\text { among networked } \\
\text { organizations }\end{array}$ & \\
\hline $\begin{array}{l}\text { Sense of } \\
\text { com- } \\
\text { munity }\end{array}$ & $\begin{array}{l}\text { Influences sense of } \\
\text { satisfaction with } \\
\text { a community } \\
\text { initiative } \\
\text { Facilitates the } \\
\text { resolution of } \\
\text { conflicts among } \\
\text { participants }\end{array}$ & & & $\begin{array}{l}\text { Facilitate social } \\
\text { capital and } \\
\text { sense of trust } \\
\text { and caring }\end{array}$ & $\begin{array}{l}\text { Can influence trust and } \\
\text { caring through } \\
\text { cooperation }\end{array}$ \\
\hline \multicolumn{6}{|c|}{$\begin{array}{l}\text { Understanding } \\
\text { of community } \\
\text { history }\end{array}$} \\
\hline $\begin{array}{l}\text { Community } \\
\text { power }\end{array}$ & $\begin{array}{l}\text { Helps cultivate a } \\
\text { power base through } \\
\text { citizen action } \\
\text { Helps cultivate a } \\
\text { power base } \\
\text { through alliances } \\
\text { with other } \\
\text { communities and } \\
\text { political groups }\end{array}$ & $\begin{array}{l}\text { Reinforces a power } \\
\text { base from which } \\
\text { to operate }\end{array}$ & $\begin{array}{l}\text { Influence the quality } \\
\text { of citizen } \\
\text { advocacy }\end{array}$ & $\begin{array}{l}\text { Influence the } \\
\text { amount of } \\
\text { political, } \\
\text { economic, and } \\
\text { social capital } \\
\text { wielded }\end{array}$ & $\begin{array}{l}\text { Facilitate collective } \\
\text { action } \\
\text { Maximize influence } \\
\text { with outside groups } \\
\text { May determine who has } \\
\text { power and influence }\end{array}$ \\
\hline $\begin{array}{l}\text { Community } \\
\text { values }\end{array}$ & $\begin{array}{l}\text { Can influence the } \\
\text { values that are } \\
\text { expressed }\end{array}$ & & & & $\begin{array}{l}\text { Can influence the premium } \\
\text { placed on cooperation } \\
\text { Can influence norms of } \\
\text { reciprocity }\end{array}$ \\
\hline $\begin{array}{l}\text { Critical } \\
\text { reflection }\end{array}$ & $\begin{array}{l}\text { Organizes needs } \\
\text { assessments as } \\
\text { the basis for } \\
\text { planning }\end{array}$ & & $\begin{array}{l}\text { Influence the ability to } \\
\text { use data for decision } \\
\text { making and action } \\
\text { Provide a basis for } \\
\text { analyzing the political } \\
\text { dynamics controlling } \\
\text { a community group }\end{array}$ & $\begin{array}{l}\text { Provide access to } \\
\text { innovative ideas } \\
\text { and approaches }\end{array}$ & \\
\hline
\end{tabular}


Table 2. Continued

\begin{tabular}{|c|c|c|c|c|}
\hline $\begin{array}{l}\text { Sense of } \\
\text { Community }\end{array}$ & $\begin{array}{l}\text { Understanding } \\
\text { of Community } \\
\text { History }\end{array}$ & $\begin{array}{l}\text { Community } \\
\text { Power }\end{array}$ & $\begin{array}{l}\text { Community } \\
\text { Values }\end{array}$ & $\begin{array}{l}\text { Critical } \\
\text { Reflection }\end{array}$ \\
\hline $\begin{array}{l}\text { Fosters a desire to } \\
\text { lead }\end{array}$ & Influences willingness & $\begin{array}{l}\text { Influences who } \\
\text { leads to lead }\end{array}$ & $\begin{array}{l}\text { Influence the diversity } \\
\text { or pluralism of the } \\
\text { leadership }\end{array}$ & \\
\hline \multirow[t]{3}{*}{$\begin{array}{l}\text { Fosters a desire to } \\
\text { participate }\end{array}$} & $\begin{array}{l}\text { Influences willingness } \\
\text { to become involved } \\
\text { Influences perceived } \\
\text { efficacy of } \\
\text { involvement }\end{array}$ & $\begin{array}{l}\text { Influences who } \\
\text { participates }\end{array}$ & $\begin{array}{l}\text { Influence the degree } \\
\text { of social control } \\
\text { exerted on } \\
\text { participants } \\
\text { Influence the } \\
\text { opportunities } \\
\text { provided } \\
\text { for inclusion }\end{array}$ & $\begin{array}{l}\text { Provides a context for collective } \\
\text { action }\end{array}$ \\
\hline & $\begin{array}{l}\text { Provides a context for } \\
\text { assessing its efficacy } \\
\text { in producing desired } \\
\text { results }\end{array}$ & & $\begin{array}{l}\text { Influences what skills } \\
\text { are viewed as } \\
\text { important to } \\
\text { community } \\
\text { initiatives }\end{array}$ & $\begin{array}{l}\text { Facilitates analytic and } \\
\text { reasoning skills in generating } \\
\text { a point of view or platform }\end{array}$ \\
\hline & $\begin{array}{l}\text { Provides a context for } \\
\text { perceiving its level of } \\
\text { resources and options }\end{array}$ & $\begin{array}{l}\text { Influences } \\
\text { resource } \\
\text { distribution }\end{array}$ & $\begin{array}{l}\text { Influence how } \\
\text { equitably resources } \\
\text { are distributed }\end{array}$ & $\begin{array}{l}\text { Facilitates an appreciation } \\
\text { for resource } \\
\text { development }\end{array}$ \\
\hline \multirow[t]{3}{*}{$\begin{array}{l}\text { Can reinforce } \\
\text { connections among } \\
\text { groups in conflict } \\
\text { Can reinforce social } \\
\text { support }\end{array}$} & $\begin{array}{l}\text { Can influence the } \\
\text { resolution of conflict } \\
\text { Highlights past critical } \\
\text { events that have } \\
\text { influenced } \\
\text { connectedness }\end{array}$ & $\begin{array}{l}\text { Influences } \\
\text { degree of } \\
\text { entrality in } \\
\text { a network }\end{array}$ & $\begin{array}{l}\text { Influence the degree } \\
\text { of cooperation and } \\
\text { inclusion within } \\
\text { a network }\end{array}$ & $\begin{array}{l}\text { Provides a context for } \\
\text { identifying strategic } \\
\text { alliances within a network }\end{array}$ \\
\hline & $\begin{array}{l}\text { Highlights past critical } \\
\text { events that have } \\
\text { influenced sense of } \\
\text { community }\end{array}$ & & $\begin{array}{l}\text { Influence the } \\
\text { importance } \\
\text { attached to } \\
\text { community } \\
\text { identity }\end{array}$ & $\begin{array}{l}\text { Facilitate an understanding of } \\
\text { forces that shape community } \\
\text { life } \\
\text { Connects the individual to a } \\
\text { broader social context }\end{array}$ \\
\hline & & & & $\begin{array}{l}\text { Provides a context for under- } \\
\text { standing how a community's past } \\
\text { contributed to current conditions }\end{array}$ \\
\hline $\begin{array}{l}\text { Facilitates power } \\
\text { sharing among } \\
\text { groups }\end{array}$ & $\begin{array}{l}\text { Influences a } \\
\text { community's sense } \\
\text { of power }\end{array}$ & & $\begin{array}{l}\text { Influences the } \\
\text { distribution } \\
\text { of power (shared } \\
\text { vs. autocratic) }\end{array}$ & $\begin{array}{l}\text { Provides a context for } \\
\text { understanding how power is } \\
\text { distributed }\end{array}$ \\
\hline $\begin{array}{l}\text { Enhances values } \\
\text { toward caring } \\
\text { and sharing }\end{array}$ & $\begin{array}{l}\text { Influences values } \\
\text { placed on trust and } \\
\text { cooperation }\end{array}$ & & & $\begin{array}{l}\text { Influences the articulation of } \\
\text { values that are shared } \\
\text { Provides a context for } \\
\text { challenging established assumptions }\end{array}$ \\
\hline $\begin{array}{l}\text { Highlights which groups } \\
\text { share affinity }\end{array}$ & $\begin{array}{l}\text { Influences the view of } \\
\text { the future } \\
\text { Helps identify barriers } \\
\text { to change } \\
\text { Provides a context for } \\
\text { comparing its status } \\
\text { to other communities }\end{array}$ & & $\begin{array}{l}\text { Influence the meaning } \\
\text { attached to } \\
\text { community } \\
\text { initiatives }\end{array}$ & \\
\hline
\end{tabular}


In view of the effect of opportunities for participation in decision making and planning on team member's involvement, satisfaction, sense of empowerment, ${ }^{16}$ and commitment as well as on the outcome of the community's efforts, ${ }^{48,51}$ it is also important for community capacity that leaders have the ability to remove barriers to participation for all community members. Community capacity is enhanced when leaders are both responsive and accessible to members. Prestby and Wandersman ${ }^{52}$ found that leaders who are viewed as successful are more visible and involved, promote cohesion and involvement, support members' planning and decision making, and provide opportunities for members to make active contributions outside meetings. Equally important for community capacity is the leader's ability to focus on both the task and process details of leadership and to determine when one may be more appropriate than another ${ }^{36,38}$ Becker $^{53}$ also has pointed out the importance of receptivity to prudent innovation and risk taking.

Finally, leaders' connectedness to other leaders in the community, state, and nation as well as participants from the community increases capacity. Warren and Warren, ${ }^{38}$ for example, assert that one of the primary tasks of a community organizer is to more effectively link the diverse structures and processes of leadership that may already exist in a community.

\section{Skills}

Both participants and leaders must have considerable skills to ensure community capacity to address local concerns (see Table 2). Yet, the skills to assess community needs and implement responsive programs often are not developed in community groups. The level of community capacity may be lower in the absence of skills to produce and implement quality plans. ${ }^{54,55}$ The ability to gain access to needed skills may also demonstrate capacity. ${ }^{26,56}$

Participants are expected to coordinate meetings, plan community activities, and be proactive in community initiatives; leaders must ensure that community efforts neither drift nor stall. Leaders must be skilled in collecting, analyzing, and reporting data on needs, opportunities, barriers, and resources; planning and evaluating community initiatives; mobilizing resources; facilitating group processes; solving problems and resolving conflicts among participants; and resisting opposing factions. Both participants and leaders must be skilled advocates, defined as "working for political, regulatory, or organizational change on behalf of a particular interest group or population" (p. 429). ${ }^{11}$ In advocating, community members recognize the political arena in which the community must operate. Acommunity with capacity usually has leaders who understand the political environment and are skilled in using the media for advocacy purposes. ${ }^{57,58}$ These leaders may also have the ability to recognize and mobilize the latent skills (and resources) present in a community.

Additional skills in group dynamics, problem solving, and conflict resolution are usually integral to community capacity. Group dynamics refers to an interaction between two or more persons, each of whom influences and is influenced by every other person. ${ }^{59}$ Much of the actual work of a community is accomplished in small task groups. Meetings are a principal method for communicating and decision making, regardless of the structures used for citizen participation. Recent studies of coalitions indicate that group process and meeting management skills may increase participants' satisfaction and degree of participation. ${ }^{54,60,61}$ Conflict resolution skills may also be important in handling 
individual-level conflicts as well as those between organizations or factions of a community. Conflict can arise over differences in goals or the means to reach goals; ideologies, perceptions, or values; or power or the distribution of resources. ${ }^{62}$ Conflict resolution skills require combining an accurate assessment of the roots of conflict with strategies to reconcile these differences.

One key to both group process and conflict resolution skills is the ability to maximize the benefit-cost ratio perceived and actually experienced by all participants. Exchange theory suggests that participating individuals, groups, and organizations have resources and skills they are willing to exchange for certain benefits. ${ }^{63,64}$ The type of exchange can vary from simple communication among participants to coordination of efforts (where participants jointly plan and integrate services and activities) to collaboration on projects, requiring contribution of resources and skills by members toward activities to achieve common goals. ${ }^{65}$ Each participant has an optimal level of resource exchange (how much is being given and received) and an optimal currency of exchange (what aspect of capital or social capital is being offered and sought). Interpersonal and interorganizational relations, in which participants clearly articulate the expected exchange transactions to optimize their own benefit-cost assessment, are most desirable because they enhance the likelihood of successful partnerships. ${ }^{66}$ As long as they perceive the benefit-cost ratio as favorable, participants may maintain a positive view of the joint endeavor and may be more likely to maintain their participation by contributing capital and social capital resources. ${ }^{60}$

\section{Resources}

One way that communities demonstrate a high degree of skill is in the acquisition of needed resources, and capacity is reflected in a community's ability to access resources and use them prudently (see Table 2). ${ }^{10}$ Resources can be either traditional capital (e.g., property and money) or social capital (e.g., the knowledge and skills of people, particularly their ability to cooperate with one another and form new associations). ${ }^{67}$ Communities need both kinds of resources. Capital resources include funding from both community and outside agencies and foundations; organized citizen groups; competent professionals, such as lawyers and accountants; meeting space and facilities for programmatic activities; media production; active and responsive mediating structures, such as churches and grassroots organizations; mechanisms for citizen input into decisions; channels for vertical and horizontal communication across sectors of the community; and technical assistance from outside the community.

Even a community that is rich in resources may lack access to technology, such as computers, photocopiers, and video cameras. Technology can provide a community with important access to innovative ideas, strategies, resources, and greater social capital. If technology is unavailable locally, a community may be able to obtain it from outside sources on an as-needed basis. To maximize the use of such technologies, communities require access to communication channels within and outside a community.

As for social capital, Fukuyama ${ }^{67}$ suggests that it is facilitated by trust. If a high level of trust exists in a community, new and varied social relationships emerge; in communities that lack trust, relationships and cooperation occur only through rules and regulations. Many health promotion efforts involve bringing people and organizations together, making trust an important component of community capacity. 
Communities can attract social capital through their capital resources. For example, resources such as funding, staffing, and responsive political institutions influence the ability of coalitions to build social capital and address social problems. ${ }^{28}$

\section{Social and Interorganizational Networks}

Strong social and interorganizational networks also enhance community capacity. In evaluating a community's social networks, one can consider (1) structural characteristics, such as size or number of linkages; (2) the relationships among network members, such as the frequency and intensity of their contacts; and (3) the benefits that members receive from their network ties, such as emotional or tangible support and access to social contacts. ${ }^{68}$ Both structural and interactional characteristics of networks have been linked to the functions of social networks. Moreover, there is considerable evidence suggesting an association between the characteristics of social networks and health status. ${ }^{68-70}$

Communities whose residents have connections to members of their neighborhood as well as loose ties to residents outside the community may be in a better position to address community-wide concerns. ${ }^{71}$ Warren and Warren ${ }^{38}$ have identified six types of neighborhoods, ranging from. "integral" neighborhoods with close contacts among members and good linkages to the larger community to "anomic" neighborhoods in which residents have few inside or outside contacts. Residents of anomic neighborhoods are unlikely to mobilize to address neighborhood or community concerns or to provide support to each other. Residents of integral neighborhoods, by contrast, are well organized internally and capable of collective action.

The extent of internal and external ties among neighborhood residents may be affected by opportunities for regular contacts among community members that foster cooperation. ${ }^{72,73}$ Since many interpersonal relationships and subsequent social networks are developed and maintained within the context of community organizations (or mediating structures) such as churches, social clubs, and work settings, the extent of neighborhood connectedness - and therefore a community's social capital-may be affected by the availability of community and neighborhood organizations. ${ }^{74}$ Israel et al. ${ }^{16}$ argue that community empowerment for health-related goals requires organizational connectedness (see Table 2). Organizational networks can promote individual empowerment through democratic management in which "members share information and power, utilize cooperative decision-making processes, and are involved in the design, implementation, and control of efforts toward mutually defined goals" (p. 152) ${ }^{16}$ By building the capacity of relevant community organizations to work together, communities may be able to address health and social issues more efficiently. By pooling the resources and expertise of many agencies, communities also can maximize their power and influence with outside groups and agencies. ${ }^{75-77}$

The developmental stage of a community's interorganizational networks may also be related to capacity. Alter and Hage ${ }^{45}$ discuss the evolution of interorganizational networks from informal, loosely linked organizations that exchange information to networks with formal linkages for the purpose of engaging in joint activities. It may be that communities with more evolved interorganizational networks are better able to mobilize to address public health or social problems than communities with networks in earlier developmental stages.

Whether interorganizational networks are vertical or horizontal may also have relevance for capacity. Networks based on vertical relationships are generally less conducive 
to building norms of reciprocity than are those built on horizontal relationships because of imbalances in power and information access (see Table 2 ) ${ }^{72}$ For example, community health coalitions and partnerships are often subsidiaries of larger public or private entities such as coalitions to combat substance abuse that may be sponsored by local government. Although vertical relationships can provide valuable resources, including support for building and maintaining social networks among the members, opportunities for the exchange of information and the development of trust and cooperation, abuses of authority by a lead agency, or conflicts between a lead agency and other members may hamper a coalition's ability to accomplish key goals and objectives. Local governments can weaken a coalition's viability through political appointments and disruptions. Government regulations and enforcement can undermine organizational morale and divert valuable resources to compliance activities.

It is important to note that the mere existence of an interorganizational network does not necessarily strengthen capacity. Network relationships that are characterized by suspicion and distrust will not provide support to network members. Consequently, a first step in enhancing community capacity may be to build trust among network members.

\section{Sense of Community}

One consequence of strong network ties is that they often produce a "sense of community" (see Table 2). ${ }^{78}$ The concept has a long-standing place in community studies, ${ }^{78-81}$ and several measures exist for the construct. ${ }^{81-83}$ Sense of community often is characterized by "caring and sharing" among the people in a community, mutual respect, generosity, and service to others that enables collective action to address local concerns and produce desired changes. ${ }^{21,80,84,85}$ McMillan and Chavis ${ }^{80}$ propose four elements characteristic of a strong sense of community: (1) membership, or a feeling of belonging; (2) influence, or a feeling that the individual and community matters; (3) fulfillment of needs, or a feeling that members' needs will be met by resources received through membership; and (4) emotional connection, or the belief that members share common experiences and history. Thus, as indicated in Table 2 , sense of community is connected to other dimensions of capacity, including participation (active membership), collective norms and values (influence), resources (fulfillment of needs), and history (emotional connection).

Community capacity to address local concerns may be reflected in a sense of community. For example, when community members disagree, the sense of connection they develop with those that they struggle may reduce conflict and facilitate reaching consensus. ${ }^{82}$

Moreover, members of a community may display varying degrees of sense of community; some neighbors may value membership and the emotional connection that community relationships offer; others may not. Those who give more support are also more likely to receive it. Some community members may desire a sense of community as an end in itself; others may see it as instrumental in gaining access to resources through membership to enhance security or happiness.

Community members can display a sense of community in various ways, such as by providing social support, tangible assistance, or information. ${ }^{86}$ In some communities, emotional connectedness may exist among people living in the same neighborhood; in others, this connectedness may be shared by coworkers or by people with common interests or cultural experiences. For example, a Latino community may have connect- 
edness and influence through extended family, church, and cultural organizations but limited connectedness and influence through public institutions, such as city government or schools. The conditions under which a sense of community is displayed may vary as well. For example, a neighborhood affected by a disaster may come together during the crisis but not sustain a pattern of caring and sharing after the crisis has passed. In general, when the four elements of membership, influence, fulfillment of needs, and emotional connection are present, then community identity is reinforced, and capacity to take constructive action is enhanced.

\section{Understanding of Community History}

A sense of community may be reinforced through the understanding of the community's history by forging a connection to the past (see Table 2). Awareness of community history also provides an important backdrop for members in planning solutions to social problems and, as such, is a key component of community capacity. ${ }^{87-89}$ How a community interprets its history may influence its willingness to become involved in a change process $^{16,87,90}$ and may also influence its views of the future.

A community's history is made up of people and events. Events include important social, political, and economic changes that have occurred both recently or more distally. The types of organizations, community groups, and community sectors involved historically in community change and the effects that change has had on them contribute to an awareness of possible future strategies. Knowledge of community history also can help identify potential barriers to change. For example, if past experiences resulted in feelings of powerlessness among community members, they might be reluctant to reengage in problem-solving activities. ${ }^{16,87,90}$ In addition, Smith $^{27}$ suggests that the level of trust and cooperation within a community is based on historical experiences. Community history can influence the resolution of conflicts that arise. Recency of conflict, nature of conflict, and the history of groups involved in the conflict are likely to affect the way the community handles conflict. Managing conflict effectively is seen as an important component for a community in producing change. ${ }^{1,21,90,91}$

Communities that have access to historical information may have greater capacity to effect change than those that do not have access. Awareness of community standing addresses how the community fits relatively to other communities. Does it see itself as better or worse off than other communities, having more or less problems to address? Does the community see itself as having resources and options for making improvement, or does it have to go outside the community to meet the needs of residents? In some respects, understanding community history is similar to Cottrell's management of relations with the larger society. ${ }^{1,91}$

\section{Community Power}

When a community develops a strong sense of history that reinforces a sense of community and connectedness, then the community is predisposed to organize around issues of shared concern. When community organizing is augured by skilled leaders and members who are well resourced, then the community has the capacity to increase its base of power and influence (see Table 2). Elements of power relate to who holds power, 
who wants power, how the power will be used, and who decides how power will be used. Power is often distributed inequitably across neighborhoods, ethnic groups, and especially income groups. A fledgling community organization that seeks power is usually at a marked disadvantage to organizations with considerably more economic resources. Efforts to change conditions related to broadly shared goals may evoke less resistance than efforts in which there are competing interests. In many communities, the agenda is determined by those with disproportionate control over resources. In rarer circumstances, those affected most by concerns, such as low-income elders or youth, have influence in defining problems and identifying culturally acceptable solutions.

Power may be evidenced in many forms, including money, material goods, status, authority, and legitimacy. The exercise of influence may be limited to those of a certain income, gender, age, or ethnicity. In some communities, influence may typically flow from powerful business leaders to elected officials whom they supported; in others, it may flow from reform-minded officials to businesses that are targeted for increased regulation or taxation.

Power may be evidenced in a variety of domains or community contexts. For example, an African American community may have tremendous capacity to influence through its churches but limited economic power if its businesses are controlled by those outside the community. The conditions under which power is displayed may vary as well. For example, a neighborhood organization may be effective in addressing a clear threat, such as the need for a traffic light at a school crossing, but less effective in creating changes necessary to address more endemic issues such as substance abuse or youth violence.

As previously mentioned, power and influence may be reflected in the degree of social capital that is present. Community power, when defined as the ability to create or resist change that matters to people who share common turf, interests, or experiences, is the application of social capital. In line with the tenets of social capital, the emphasis is on power with others, not control over them. ${ }^{92}$ The term win-lose relationships characterizes power as limited and as a basis for control over others. ${ }^{62}$ By contrast, win-win relationships characterize power as less limited and based on mutual respect, generosity, and service to others. ${ }^{19}$

In working with communities, professionals may need to guard against win-lose relationships. For example, when professional or grant-giving organizations sponsor community initiatives, they often assert their authority by requiring the community to tailor its goals, objectives, and approaches to the sponsor's specifications. Such requirements, if not negotiated, can stifle community initiative and ownership when local groups perceive that their projects are being wrested away from them. ${ }^{93}$ Hence, an important challenge facing professionals is the transformation of power over to power with communities by engaging in mutual exploration, dialogue, and problem solving..$^{92,94}$

\section{Community Values}

The previous section emphasizes the transformation of power over to power with as capacity enhancing. Implied in this shift is the value that shared influence is a greater good. This shift illustrates that for community capacity to be fully realized, community initiatives must have a clearly defined value orientation. Community capacity is not a value-free or objective term but embodies within it expectations of norms, standards, and desired attributes. Community initiatives are embedded in the life and meaning of 
particular communities, whether defined through geography, institutions, or mutual interests and identity.

We maintain that a community's ability to articulate a clear set of values is integral to capacity, and health professionals who work with community groups can play an important role in challenging a group to surface its value assumptions. Such interactions require professionals to proceed with caution as they can experience two potentially contradictory dynamics regarding value assumptions. The first is the set of core public health values to which most professionals subscribe: to promote and preserve good health and to relieve suffering through beneficence, "doing good." In practice, the ethic of doing good has supported the values of social justice and the equitable distribution of resources and conditions for improved health. ${ }^{95}$ Other core professional values commonly described in the health education literature include democracy ${ }^{58}$ community participation, ${ }^{58}$ collaboration, ${ }^{96}$ community control, social responsibility, and respect for cultural diversity. ${ }^{97-100}$ Some have also emphasized the value of individual responsibility. ${ }^{101,102}$

The second value base for community capacity stems from how communities develop consensus about their values and visions for health. Although this process is critical to the development of community capacity, it should not be romanticized. ${ }^{94}$ Some communities may argue for values that reflect racism, homophobia, or other harmful perspectives and that contradict the value of social justice. For instance, one can argue that communities that successfully organize to exclude a race, class, or ethnic group from local home ownership may have capacity, but we do not consider this as consonant with the construct of community capacity in a democracy. Moreover, few communities are homogeneous, creating the possibility of sharp conflicts on basic values that influence public health, such as reproductive rights, the role of parents in sex education, the rights of immigrants to public services, and so on.

Because values underlie the other dimensions of community capacity, they are both part of the process of creating community capacity and the expected outcomes of these community processes (see Table 2). Two hypotheses provide a guide for assessing the importance of values: (1) If the community identifies and acts on the core set of values, then community capacity will be increased; and (2) if there is an increase in shared community values, then community capacity will be increased. In sum, we posit that community health professionals should be cognizant that their value assumptions may not be confluent with that of the community. By clearly identifying one's value assumptions, the professional may be more effective in engaging the community in a process of surfacing and reaching consensus on its own value sets.

\section{Critical Reflection}

The development of a clear set of community values is predicated on a community's capacity to engage in critical reflection (see Table 2). Since the 1980s, journal articles have urged Americans to increase their critical thinking to reform civic and economic life. Critical thinking is defined by Stephen Brookfield as the ability to reflect on the assumptions underlying our and others' ideas and actions and to contemplate alternative ways of thinking and living. ${ }^{103}$ Critical reflection includes the ability to reason logically ${ }^{104}$ and scrutinize arguments for ambiguity. ${ }^{105}$ Brookfield believes critical reflection incorporates emancipatory, dialectical, and emotion-motivated learning. 
Emancipatory learning, or education for empowerment (within the field of health education), is the process by which community members gain an understanding of forces in their environment to enable them to act to promote both individual and social changes. ${ }^{16,106-110}$ The literature on empowerment education has supported the importance of dialectical thinking, praxis, and Paulo Freire's critical consciousness. Dialectical thinking welcomes contradictions, paradoxes, and the presumption of constant change in communities. ${ }^{18,103}$ Praxis emerges out of dialectical thinking, as each community action creates contradictory outcomes and the continual cycle of collective reflection on the outcomes, new actions, and new reflections. Freire's critical consciousness in the reflection/action cycle is achieved when people make the connections between themselves and the broader social context, when they reflect on their own roles in society, when they understand the history and conditions of a social problem, and when they believe they can participate in collective change. ${ }^{111}$

Critical reflection is a lived activity of action and reflection within one's community for the purpose of challenging assumptions and creating change toward the core public health values of democratic participation and equity. Critical reflection involves challenging assumptions and received wisdom and integrating values of social justice to generate alternative visions of the world. This challenge includes an analysis of personal and community values as part of creating possibilities for change. It is hypothesized that communities and community organizations that create mechanisms for self-reflection, for constructing their own identity, and for analyzing social conditions will have greater community capacity to maintain change efforts and improve community health.

\section{DISCUSSION AND CONCLUSION}

This article reports on the deliberations resulting from a CDC-sponsored symposium to understand the complexities of community capacity as a construct. At the beginning of this article, we noted that community capacity is a complex, multidimensional, and dynamic concept that requires precision for assessing community assets and for developing appropriate interventions. Table 1 summarizes the dimensions of capacity that resulted from the symposium, and the body of the article further explains these dimensions. Table 2 illustrates how the dimensions may be linked. We do not believe that the dimensions of community capacity that we have identified are exhaustive, and we further recognize that capacity is a construct that has different meanings in different contexts. Further reflection and reaction from diverse communities will undoubtedly alter and enrich the construct.

We caution the reader not to adopt the items in Table 1 as a checklist but to use the table as a point of departure for dialogue. The complexity of community capacity as a construct and the current lack of adequate measures suggest the challenge that remains for operationalizing ways to assess capacity in communities. However, even at this early stage, we believe that the dimensions can be used by citizen groups involved in efforts to assess and develop community capacity. We envision that community health professionals may share the table with community groups with whom they work and encourage interaction regarding the table's relevance and implications for community initiatives that are underway. Such discussions of capacity are best considered early in the community development process and may be viewed as a positive measure that reflects on a community's preparedness to address public health and other societal issues. 


\section{References}

1. Cottrell L: The competent community, in Warren $\mathrm{R}$ (ed.): New perspectives on the American community. Chicago, Rand-McNally, 1977, pp. 195-209.

2. Parker E, Eng E: Conceptualizing Community Problem-Solving Capacity: Results of a Grounded Theory Study. Unpublished paper, University of Michigan, 1995.

3. Fawcett SB, Paine-Andrews A, Francisco VT, Schultz JA, Richter KP, Lewis RK, Williams EL, Harris KJ, Berkley JY, Fisher JL, Lopez CM: Using empowerment theory in collaborative partnerships for community health. American Journal of Community Psychology 23:677-697, 1995.

4. Fawcett SB, Paine-Andrews A, Francisco VT, Schultz JA, Richter KP, Lewis RK, Harris KJ, Williams EL, Berkley JY, Lopez CM, Fisher JL: Empowering community health initiatives through evaluation, in Fetterman DM, Kaftarian SJ, Wandersman A (eds.): Empowerment Evaluation: Knowledge and Tools for Self-Assessment \& Accountability. Thousand Oaks, CA, Sage, 1996, pp. 161-187.

5. Sashkin M, Burke WW: Organization development in the 1980's. Journal of Management 13(2):393-417, 1987.

6. Scott WR, Shortell SM: Organizational performance: Managing for efficiency and effectiveness, in Shortell SM, Kaluzny AD (eds.): Health Care Management: A Text in Organization Theory and Behavior (2nd ed.). New York, John Wiley, 1988, pp. 418-457.

7. Clark NM, McLeroy KR: Creating capacity: Establishing a health education research agenda. Health Education Quarterly 22(3):270-272, 1995.

8. Meissner HI, Bergner L, Marconi KM: Developing cancer control capacity in state and local public health agencies. Public Health Reports 107:15-23, 1992.

9. McLeroy K: Community Capacity: What Is It? How Do We Measure It? What Is the Role of the Prevention Centers and CDC? Paper presented at the Sixth Annual Prevention Centers Conference, Centers for Disease Control and Prevention, National Center for Chronic Disease Prevention and Health Promotion, Atlanta, GA, February 1996.

10. Rogers T, Howard-Pitney B, Lee H: An Operational Definition of Local Community Capacity for Tobacco Prevention and Education. Palo Alto, CA: Stanford Center for Research in Disease Prevention, Stanford University, 1995.

11. Green L, Kreuter M: Health Promotion Planning: An Educational and Environmental Approach. Mountainview, CA, Mayfield, 1991.

12. Kretzmann JP, McKnight JL: Building Communities From the Inside Out: A Path Toward Finding and Mobilizing a Community's Assets. Chicago, ACTA Publications, 1993.

13. Goodman RM, Steckler A, Hoover S, Schwartz R: A critique of contemporary community health promotion approaches: Maine-A multiple case study. American Journal of Health Promotion 7(3):208-220, 1993.

14. Steuart G: Social and behavioral change strategies, in Phillips HT, Gaylord SA (eds.): Aging and Public Health. New York, Springer, 1985.

15. Goodman RM, Wheeler FC, Lee PR: Evaluation of the Heart to Heart Project: Lessons from a community-based chronic disease prevention project. American Journal of Health Promotion 9:443-455, 1995.

16. Israel BA, Checkoway B, Schulz A, Zimmerman M: Health education and community empowerment: Conceptualizing and measuring perceptions of individual organizational and community control. Health Education Quarterly 21(2):149-170, 1994.

17. Perkins DD, Zimmerman MA: Empowerment theory research and application. American Journal of Community Psychology 23(5):569-579, 1995.

18. Rappaport J: In praise of paradox: A social policy of empowerment over prevention. American Journal of Community Psychology 9(1):1-25, 1981.

19. Wallerstein N: Powerlessness empowerment and health: Implications for health promotion programs. Health Promotion 6:197-205, 1992. 
20. Eng E, Parker E: Measuring community competence in the Mississippi Delta: The interface between program evaluation and empowerment. Health Education Quarterly 21(2):199-220, 1994.

21. Iscoe I: Community psychology and the competent community. American Psychologist 29:607-613, 1974.

22. Haglund B, Weisbrod RR, Bracht N: Assessing the community: Its services needs leadership and readiness, in Bracht N (ed.): Health Promotion at the Community Level. Newbury Park, CA, Sage, 1990.

23. Kumpfer K, Turner C, Hopkins R, Librett J: Leadership and team effectiveness in community coalitions for the prevention of alcohol and other drug abuse. Health Education Research: Theory and Practice 8(3):359-374, 1993.

24. Minkler $M$, Wallerstein $\mathrm{N}$ : Improving health through community organization and community building, in Glanz K, Lewis FM, Rimer BK (eds.): and Health Behavior Health Education (2nd ed.). San Francisco, Jossey-Bass, 1996, pp. 241-269.

25. Zimmerman MA: Psychological empowerment: Issues and illustrations. American Journal of Community Psychology 23(5):581-599, 1995.

26. Florin P, Mitchell R, Stevenson J: Identifying technical needs in community coalitions: A developmental approach. Health Education Research: Theory and Practice 8(3):417-432, 1993.

27. Smith S: Social Capital Community Coalitions and the Role of Institutions. Unpublished manuscript, Duke University, Durham, NC, 1995.

28. Fawcett SB, Sterling TD, Paine-Andrews A, Harris KJ, Francisco VF, Richter KP, Lewis RK, Schmid TL: Evaluating Community Efforts to Prevent Cardiovascular Diseases. Atlanta, GA, Centers for Disease Control and Prevention, U.S. Department of Health and Human Services, 1995.

29. Minkler M: Health education health promotion and the open society: An historical perspective. Health Education Quarterly 16(1):17-30, 1989.

30. Gruber J, TrickettEJ: Can we empower others? The paradox of empowerment in the governing of an alternative public school. American Journal of Community Psychology 15(3):353-371, 1987.

31. Wandersman A, Florin P, Friedmann R, Meier R: Who participates, who does not and why? An analysis of voluntary neighborhood organizations in the United States and Israel. Sociological Forum 2(3):534-555, 1987.

32. Chavis DM, Wandersman A: Sense of community in the urban environment: A catalyst for participation and community development. American Journal of Community Psychology 18(1):55-81, 1990.

33. Prestby J, Wandersman A, Florin P, Rich R, Chavis D: Benefits costs incentive management and participation in voluntary organizations: A means to understanding and promoting empowerment. American Journal of Community Psychology 18:117-151, 1990.

34. Florin P, Wandersman A: Cognitive social learning and participation in community development: A comparison of standard and cognitive social learning variables. American Journal of Community Psychology 12:689-708, 1984.

35. Parham D, Goodman RM, Steckler A, Schmid J, Koch G: Adoption of health education: Tobacco prevention curricula in North Carolina school districts. Family \& Community Health 16(3):54-64, 1993.

36. Brown C: The Art of Coalition Building: A Guide for Community Leaders. New York, American Jewish Committee, 1984.

37. McKillip J: Need Analysis: Tools for the Human Services and Education. Newbury Park, CA, Sage, 1987.

38. Warren RB, Warren DI: The Neighborhood Organizer's Handbook. South Bend, IN, University of Notre Dame Press, 1977.

39. Marti-Costa S, Serrano-Garcia I: Needs assessment and community development: An ideological perspective. Prevention in Human Services 2(4):75-88, 1983. 
40. Arnstein S: A ladder of citizen participation. American Institute of Planners Journal, July, 1969, pp. 216-224.

41. Uphoff N, Cohen J, Goldsmith A: Feasibility and Application of Rural Development Participation: A State of the Art Paper. Ithaca, NY: Rural Development Committee Center for International Studies, Cornell University, 1979.

42. Checkoway B, Van Til J: What do we know about citizen participation? A selective review of research, in Langton S (ed.): Citizen Participation in America. Urbana, University of Illinois Press, 1978, pp. 28-56.

43. Berger PL, Neuhaus RJ: Mediating structures and the dilemmas of the welfare state, in To Empower People: The Role of Mediating Structures in Public Policy. Washington, DC, American Enterprise Institute for Public Policy Research, 1977.

44. Wickizer TM, Von Korff M, Cheadle A, Maeser J, Wagner E, Pearson D, Beery W, Psaty BM: Activating communities for health promotion: A process evaluation method. American Journal of Public Health 83(4):561-567, 1993.

45. Alter C, Hage J: Organizations Working Together. Newbury Park, CA, Sage, 1993.

46. Mayer NS, Blake JL: Keys to the Growth of Neighborhood Development Organizations. Washington, DC, The Urban Institute, 1981.

47. Miller FD, Malia G, Tsemberis S: Community Activism and the Maintenance of Urban Neighborhoods. Paper presented at the 87th annual meeting of the American Psychological Association, New York, October, 1979.

48. Knoke D, Wood JR: Organizing for Action: Commitment in Voluntary Associations. New Brunswick, NJ, Rutgers University Press, 1981.

49. Schoenberg S, Rosenbaum PL: Neighborhoods That Work: Sources of Viability in the Inner City. New Brunswick, NJ, Rutgers University Press, 1980.

50. Yates D: Neighborhood Democracy and Health. Lexington, MA, Lexington Books, 1973.

51. Giarmartino GA, Wandersman A: Organizational climate correlations of viable urban block organizations. American Journal of Community Psychology 11:529-541, 1983.

52. Prestby J, Wandersman A: An empirical exploration of a framework of organizational viability. Journal of Applied Behavioral Science 21(3):287-305, 1985.

53. Becker MH: Predictors of innovative behavior among local health officers. Public Health Reports 84:1063-1068, 1969.

54. Butterfoss F, Goodman RM, Wandersman A: Community coalitions for prevention and health promotion: Factors predicting satisfaction, participation, and planning. Health Education Quarterly 23(1):65-79, 1996.

55. Butterfoss F, Goodman RM, Wandersman A, Valois R, Chinman M: The plan quality index: An empowerment evaluation tool for measuring and improving the quality of plans, in Fetterman D, Kaftarian S, Wandersman A. (eds.): Empowerment Evaluation Thousand Oaks, CA, Sage, 1996, pp. 304-331.

56. Linney JA, Wandersman A: Empowering community groups with evaluation skills: The Prevention Plus III model, in Fetterman DM, Kaftarian SJ, Wandersman A (eds.): Empowerment Evaluation: Knowledge and Tools for Self-Assessment \& Accountability. Thousand Oaks, CA, Sage, 1996, pp. 259-276.

57. Wallack L, Dorfman L, Jernigan D, Themba M: Media Advocacy and Public Health: Power for Prevention. Thousand Oaks, CA, Sage, 1993.

58. Schwartz R, Goodman RM, Steckler A: Policy advocacy interventions for health promotion and education: Advancing the state of practice. Health Education Quarterly 22(4):421-426, 1995.

59. Bradford LP: Group Development. Fairfax, VA, Learning Resources Corporation, 1974.

60. Rogers T, Howard-Pitney B, Feighery EC, Altman DG, Endres JM, Roeseler AG: Characteristics and participant perceptions of tobacco control coalitions in California. Health Education Research 8(3):345-358, 1993.

61. Kegler M: Community Coalitions for Tobacco Control: Factors Influencing Implementation. Ph.D. dissertation, University of North Carolina at Chapel Hill, 1995. 
62. Deutsch M: The Resolution of Conflict: Constructive and Destructive Processes. New Haven, CT, Yale University Press, 1973.

63. Levine S, White P: Exchange as a conceptual framework for the study of interorganizational relationships. Administrative Science Quarterly 5:583-601, 1961.

64. Cook K (ed.): Social Exchange Theory. Newbury Park, CA, Sage, 1987.

65. Feighery E, Rogers T: Building and Maintaining Effective Coalitions. Palo Alto, CA, Stanford Health Promotion Resource Center, 1990.

66. DiSogra L, Glanz K, Rogers T: Working with community organizations for nutrition intervention. Health Education Research 5:459-465, 1990.

67. Fukuyama F: Trust: The Social Virtues and the Creation of Prosperity. New York, Free Press, 1995.

68. Israel BA: Social networks and health status: Linking theory research and practice. Patient Counseling and Health Education 4(2):65-79, 1982.

69. Israel BA, Rounds K: Social networks and social support: A synthesis for health educators. Advances in Education and Promotion 2:311-351, 1987.

70. Heaney CA, Israel BA: Social networks and social support in health education, in Glanz K, Lewis FM, Rimer BK (eds.): Health Behavior and Health Education (2nd ed.). San Francisco, Jossey-Bass, 1996.

71. Granovetter MS: The strength of weak ties. American Journal of Sociology 78(6):1360-1380, 1973.

72. Putnam R: Making Democracy Work. Princeton, NJ, Princeton University Press, 1993.

73. Putnam R: The prosperous community: Social capital and public life. American Prospect 13(Spring):35-42, 1993.

74. Gottlieb NH, McLeroy KR: Social health, in O'Donnell MP, Harris JS (eds.): Health Promotion in the Workplace (2nd ed.). Albany, NY, Delmar, 1994.

75. Black T: Coalition building-some suggestions. Child Welfare 62(3):263-268, 1983.

76. Butterfoss FD, Goodman RM, Wandersman A: Community coalitions for health promotion and disease prevention. Health Education Research 8(3):315-330, 1993.

77. Goodman RM, Steckler A, Kegler M: Mobilizing organizations for health enhancement: Theories of organizational change, in Glanz K, Lewis FM, Rimer BK (eds.): Health Behavior and Health Education: Theory Research and Practice (2nd ed.). San Francisco, Jossey-Bass, 1996, 287-312.

78. Doolittle RJ, MacDonald D: Communication and a sense of community in a metropolitan neighborhood: A factor analytic examination. Communication Quarterly 26(3):2-7, 1978.

79. Sarason SB: The Psychological Sense of Community: Prospects for a Community Psychology. San Francisco, Jossey-Bass, 1974.

80. McMillan DW, Chavis DM: Sense of community: A definition and theory. Journal of Community Psychology 14:6-23, 1986.

81. Glynn TJ: Psychological sense of community: Measurement and application. Human Relations 34:789-818, 1981.

82. Chavis DM, Florin P, Rich R, Wandersman A: The Role of Block Associations in Crime Control and Community Development: The Block Booster Project. Final report to the Ford Foundation, New York, 1987.

83. Linney JA, Wandersman A: Prevention Plus III: Assessing Alcohol and Other Drug Prevention Programs at the School and Community Level. Rockville, MD, Office of Substance Abuse Prevention, U.S. Department of Health and Human Services, 1991.

84. Bachrach KM, Zautra AJ: Coping with a community stressor: The threat of a hazardous waste facility. Journal of Health and Social Behavior 26:127-141, 1985.

85. Newbrough JR, Chavis DM (eds.): Psychological sense of community II: Research and applications. Journal of Community Psychology 14(4):385-414, 1986.

86. Paine AL, Francisco VT, Fawcett SB: Assessing community health concerns and implementing a microgrant program for self-help initiatives. American Journal of Public Health 84(2):316$318,1994$. 
87. Bracht N, Kingsbury L: Community organization principles in health promotion: A five-stage model, in Bracht N (ed.): Health Promotion at the Community Level. Newbury Park, CA, Sage, 1990.

88. Johnson MA, Mullins P: Community competence in religious congregations. American Journal of Community Psychology 18(2):259-280, 1990.

89. Mulvey A, Silka L: A community training model incorporating history empowerment and ecology. Journal of Community Psychology 15:365-375, 1987.

90. Gonzalez VM, Gonzalez JT, Freeman V, Howard-Pitney B: Health Promotion in Diverse Cultural Communities. Palo Alto, CA, Health Promotion Resource Center, Stanford Center for Research in Disease Prevention, Stanford University, 1991.

91. Goeppinger J, Baglioni AJ Jr: Community competence: A positive approach to needs assessment. American Journal of Community Psychology 13(5):507-523, 1985.

92. Labonte R, Robertson A: Delivering the goods, showing our stuff: The case for a constructivist paradigm for health promotion research and practice. Health Education Quarterly 24(4):431$447,1996$.

93. Hayes MV, Willms SM: Heal thy community indicators: The perils of the search and the paucity of the find. Health Promotion International 5(2):161-166, 1990.

94. Labonte R: Health promotion and empowerment: Reflections on professional practice. Health Education Quarterly 21(2):253-268, 1994.

95. Last M: Ethics and public policy, in Last M (ed.): Public Health \& Preventive Medicine. Norwalk, CT, Appleton \& Lange, 1992.

96. Gray B: Conditions facilitating interorganizational collaboration. Human Relations 38:911936, 1985.

97. Minkler M: Ten commitments for community health education. Health Education Research 9(4):527-534, 1994.

98. Faden RR, Faden AL: The ethics of health education as public health policy, in Matthews B (ed.): The SOPHE Heritage Collection of Health Education Monographs. Oakland, CA, Third Party Publishing, 1982.

99. Fawcett SB: Some values guiding community research and action. Journal of Applied Behavior Analysis 4:621-636, 1991.

100. Simonds SK: Health education: Facing issues of policy ethics and social justice. Health Education Monographs 6(suppl. 2):18-27, 1978.

101. Knowles J: The responsibility of the individual. Daedalus 106:57-80, 1977.

102. Fuchs V: Who Shall Live? Health Economics and Social Choice. New York, Basic Books, 1974.

103. Brookfield SD: Developing Critical Thinker: Challenging Adults to Explore Alternative Ways of Thinking and Acting. San Francisco, Jossey-Bass, 1987.

104. Hallet GL: Logic for the Labyrinth: A Guide to Critical Thinking. Washington, DC, University Press of America, 1984.

105. Ennis RH: A Concept of Critical Thinking. Harvard Educational Review 32(1):81-111, 1962.

106. Wallerstein N, Bernstein E (eds.): Community empowerment participatory education and health: Part I (Special issue). Health Education Quarterly 21(2), 1994.

107. Wallerstein N, Bernstein E (eds.): Community empowerment participatory education and health: Part II (Special issue). Health Education Quarterly 21(3), 1994.

108. Shor I, Freire P: A Pedagogy for Liberation: Dialogues on Transforming Education. Boston, Bergin \& Garvey, 1987.

109. Freire P: Pedagogy of the Oppressed. New York, Seabury Press, 1970.

110. Habermas J: Communication and the Evolution of Society. Boston, Beacon, 1979.

111. Shor I: Empowering Education: Critical Teaching for Social Change. Chicago, University of Chicago Press, 1992. 